Review

\title{
Intestinal Iron Homeostasis and Colon Tumorigenesis
}

\section{Xiang Xue ${ }^{1}$ and Yatrik M. Shah ${ }^{1,2, *}$}

1 Department of Molecular \& Integrative Physiology, University of Michigan, Ann Arbor, MI 48109, USA; E-Mail: xxue@umich.edu

2 Department of Internal Medicine, Division of Gastroenterology, University of Michigan, Ann Arbor, MI 48109, USA

* Author to whom correspondence should be addressed; E-Mail: shahy@umich.edu; Tel: +1-734-6150-567; Fax: +1-734-9368-813.

Received: 3 May 2013; in revised form: 29 May 2013 / Accepted: 7 June 2013 /

Published: 28 June 2013

\begin{abstract}
Colorectal cancer (CRC) is the third most common cause of cancer-related deaths in industrialized countries. Understanding the mechanisms of growth and progression of $\mathrm{CRC}$ is essential to improve treatment. Iron is an essential nutrient for cell growth. Iron overload caused by hereditary mutations or excess dietary iron uptake has been identified as a risk factor for CRC. Intestinal iron is tightly controlled by iron transporters that are responsible for iron uptake, distribution, and export. Dysregulation of intestinal iron transporters are observed in CRC and lead to iron accumulation in tumors. Intratumoral iron results in oxidative stress, lipid peroxidation, protein modification and DNA damage with consequent promotion of oncogene activation. In addition, excess iron in intestinal tumors may lead to increase in tumor-elicited inflammation and tumor growth. Limiting intratumoral iron through specifically chelating excess intestinal iron or modulating activities of iron transporter may be an attractive therapeutic target for CRC.
\end{abstract}

Keywords: iron; colorectal cancer; divalent metal transporter-1 (DMT-1); hepcidin; HIF; ferroportin (FPN)

\section{Introduction}

Colorectal cancer (CRC) is the third most common cancer in both men and women, and is the second leading cause of cancer death in the United States [1]. Each year about 150,000 new cases will be 
diagnosed in the United States [1], in European countries it is significantly higher, with the expected cases to be over 400,000 per year [2,3]. Current treatments for CRC are effective at early stages of disease, however over $40 \%$ of patients at the time of diagnosis present with late stage CRC where standard therapies are not effective [4]. Understanding the precise mechanisms that are critical in the progression of colon carcinogenesis may provide better treatment strategies for CRC. The etiological factors and molecular mechanisms underlying the pathogenesis of CRC are multifactorial and complex [5]. In addition to inherited mutations and environmental interactions, dietary nutrients play a key role in the development of CRC [6].

\section{Mechanism of Iron Absorption}

Iron levels must be precisely controlled to meet systemic demands but avoiding deleterious iron overload [7]. A major node of regulation occurs at the proximal small intestine. Dietary iron absorption occurs mainly in the lumen of duodenum by a tightly regulated process. This process is influenced by the individual's iron status and by several factors in the diet. Ascorbic acid enhances, whereas polyphenols and calcium inhibit iron absorption [8-10]. There are two major forms of nutritional iron, heme and non-heme. Iron acquired from meat is $40 \%$ heme iron and $60 \%$ non-heme iron. In addition, the iron acquired from fruits, vegetables, grains, and nuts is non-heme iron [11]. Heme is taken up from the gut lumen into intestinal epithelial cells as an intact metalloporphyrin. Currently the transporter responsible for heme uptake is unclear (proposed to be PCFT/HCP1, SLC46A1) [12,13]. After entering the enterocyte, heme is broken down by heme oxygenase into ferrous iron $\left(\mathrm{Fe}^{2+}\right)$, bilirubin and carbon monoxide [14]. Dietary non-heme iron is in the ferric form $\left(\mathrm{Fe}^{3+}\right)$ and is reduced to ferrous iron $\left(\mathrm{Fe}^{2+}\right)$ by ferric reductases such as duodenal cytochrome b (Dcytb) [15], and then is transported by the divalent metal transporter 1 (DMT-1, also known as SLC11A2, NRAMP2 and DCT1) at the apical surface of enterocytes [16,17]. Dietary iron can be stored as ferritin within the enterocytes [18], or under increased systemic requirements of iron, $\mathrm{Fe}^{2+}$ is exported across the basolateral membrane of the enterocyte into the circulation by ferroportin (FPN, also known as IREG1) [19,20]. Upon release from FPN, $\mathrm{Fe}^{2+}$ is oxidized into $\mathrm{Fe}^{3+}$ by ferroxidase such as ceruloplasmin (Cp) and hephaestin (HEPH) [21-23], and rapidly binds to plasma transferrin [24] (Figure 1A). Transferrin-diferric iron complex is taken up into cells by binding with transferrin receptor (TfR) on the cell surface, followed by internalization through clathrin-mediated endocytosis [25,26] (Figure 1B). The efficiency of colonic iron absorption is only about $14 \%$ of duodenum, which is due to a lower expression of iron absorptive genes such as DMT1, TfR and ferritin in normal colon tissues than duodenum [27,28]. Interestingly, FPN is highly expressed in the colon, to the same extent as the duodenum [27]. The expression of these iron transporters is altered in CRC and is discussed in detail below. Intestinal iron absorption is mainly regulated by hypoxia-inducible factor (HIF)-2 $\alpha$, hepcidin, and iron regulatory proteins (IRPs) and their role in iron homeostasis has been reviewed in detail elsewhere [29-34]. In addition to local regulation of iron transporters by HIFs, hepcidin is an antimicrobial peptide that is synthesized in the liver and secreted into the circulation, binds to FPN on the basolateral membrane and leads to the internalization and degradation of the iron exporter [35-37]. 
Figure 1. Mechanism of iron accumulation in colon tumors. (A) Apical increase in divalent metal transporter 1 (DMT-1) leads to increase in uptake of luminal iron in tumors. The iron is further sequestered in colon epithelial cells through a decrease in hephaestin (HEPH) and increase in hepcidin-mediated ferroportin (FPN) degradation; (B) An alternative or complimentary mechanism leading to increase of intratumoral iron is through the increase in transferrin-TfR mediated uptake of circulating iron.

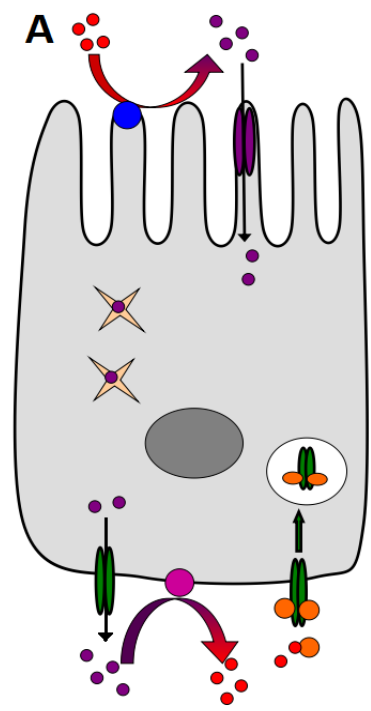

B

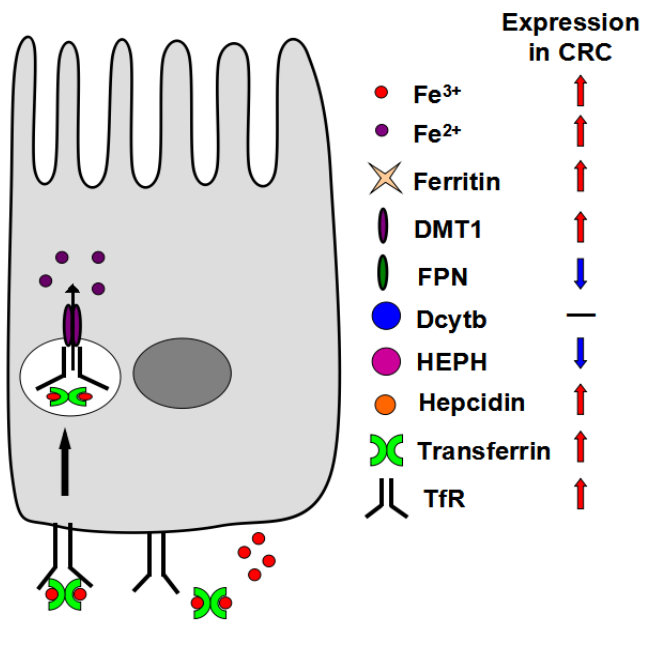

\section{Increased Systemic Iron Is a Risk Factor for CRC}

As an indispensable nutrient for life, iron is essential for erythropoiesis and numerous other cellular processes including cell growth. Iron deficiency leads to anemia and affects millions of people worldwide. On the other hand, iron overload caused by hereditary mutations or excess dietary iron uptake has been identified as a risk factor for CRC through population and animal studies [38]. A retrospective literature review identified 26 individual reports that assessed the role of iron exposure in CRC risk [39]. Each report was graded and scored based on unbiased rigorous criteria to evaluate the validity of each report. From the twenty-six reports, eleven were given an acceptable quality rating. Nine of the eleven reports that were graded high demonstrated a positive correlation with increased CRC risk and iron exposure. A recent meta-analysis also supports a positive dose-response correlation of dietary iron intake with CRC risk [6]. However, to be pointed out, a nested-control study that measured iron status in women did not support the role of iron in the pathogenesis of CRC [40].

\subsection{Hemochromatosis}

Mutations in the hemochromatosis gene HFE can lead to hereditary hemochromatosis due to inappropriately high iron uptake from the diet resulting from decreased hepatic expression of the iron regulatory hormone hepcidin $[41,42]$. These individuals have an increased risk of developing CRC. Recent studies showed that the risk of developing CRC is doubled in patients with the two major HFE mutations, C282Y and H63D [43,44]. When these carriers consume high quantities of iron, the cancer risk is further increased [45], implying iron overload is a contributory factor to colon tumorigenesis. 


\subsection{Dietary Consumption}

Red meat is a major component of diet in Western countries [11]. A recent meta-analysis indicated that red and processed meat intake is associated with increased risk of colorectal adenomas [46], which support that iron may play a key role in an early stage of the colorectal carcinogenesis. In large population-based studies, the CRC risk is positively associated with the amount of consumed red meat $[47,48]$. Increased risk of CRC in red meat consumers is entirely dependent on heme iron abundance in red meat and independent of dietary fat content or inorganic iron [48-50]. Feeding rats with heme leads to damage in the colonic mucosa surface and compensatory hyperplasia [50]. Down-regulation of inhibitors of proliferation such as Wnt inhibitory factor 1, Indian hedgehog and BMP2 are proposed as a mechanism for heme-induced colonic hyperplasia [51]. Furthermore, heme iron from red meat could also promote colon carcinogenesis through its catalytic effects on the formation of carcinogenic $N$-nitroso compounds or cytotoxic and genotoxic secondary lipid oxidation products, such as 4-hydroxy-2(E)-nonenal (HNE) [52-54]. Trapping heme with calcium phosphate or green vegetable derived chlorophyll could inhibit the cytolytic and hyperproliferative effects of dietary heme and reduce CRC risk in meat-eaters [49,55-58]. In addition, ferrous iron is widely supplemented in the American diet [39]. Supplemental iron is positively associated with distal colon cancer, which may cause enhanced free radical production in the colon $[59,60]$.

\subsection{Mouse Models of CRC}

1,2-dimethylhydrazine $(\mathrm{DMH})$ is a carcinogen that initiates colorectal tumorigenesis in rodent models. Chronic treatment of DMH up to 20 -weeks will lead to a tumor response with a $100 \%$ incidence with multiple tumors in the distal colon [61]. In mice fed iron-rich diets, DMH-induced colon tumors were robustly increased with respect to tumor size and multiplicity [62]. Consistent with this data, iron enriched diets increased colon tumorigenesis in genetic models of colon cancer [63].

\section{Low Iron Is Protective in CRC}

Two separate studies using genetic mouse models of CRC demonstrated that mice on low-iron diet had decreased colon tumors compared to mice on an iron-replete diet $[63,64]$. A robust decrease in tumor cell proliferation was noted in both studies following low iron treatment. Assessing decreased iron stores in humans is very difficult since the major parameters to assess body iron store such as serum iron, hematocrit, transferrin saturation, and ferritin are not accurate or sensitive measures [65]. These parameters can display large variations in healthy populations. Moreover there are gender and age specific changes in several of these parameters. However, assessing the cancer risk in frequent blood donors who deplete iron stores through loss of blood compared to those who do not donate blood found a significant decrease in CRC risk [66]. More recently a multi-center single blinded clinical trial in which individuals were phlebotomized at six-month intervals for an accrual period of 3.5 years and a follow-up period of 2.5 years demonstrated that the phlebotomized group was associated with a lower risk of all cancers [67]. More specifically a significant decrease in CRC risk was demonstrated. Moreover, the phlebotomized group that did get cancer had a decreased mortality compared to the control group with cancer. 


\section{Altered Local Iron Homeostasis in CRC}

The expression of proteins associated with cellular iron uptake machinery such as DMT-1 and TfR1 is up-regulated in CRC, whereas the expression of the iron export proteins such as FPN and HEPH is decreased in advanced CRC [38] (Figure 1). Consistent with this data, iron content is increased in human colorectal tumors and tumors from mouse models of CRC compared to normal adjacent tissues as demonstrated by Prussian blue staining [64,68]. Similar alterations that result in increased iron acquisition and decreased iron export by the tumor are also observed for other tumors such as breast $[69,70]$. This data demonstrate that local iron requirements are increased in tumors compared to normal tissues, and the increase in intratumoral iron may be critical in tumor growth.

\subsection{DMT-1}

DMT-1 is expressed at significant levels in the colon and is dramatically increased by iron-deficient diet [71]. DMT-1 is highly induced in colon adenomas and carcinomas compared with normal colon tissue isolated from patients [72-74]. Two independent groups have recently demonstrated that the expression of DMT-1 protein is increased in mouse intestinal tumors, and this increase is dependent on HIF signaling pathway and Wnt signaling pathway, respectively [63,64].

\subsection{Transferrin and $T f R$}

A large cohort study found that high transferrin saturation level is associated with excess risk for CRC [75]. In colon tissue, TfR1 is expressed in normal colonocytes [22], and further increased in CRC of Dukes A or B grade [76]. The expression level of TfR1 regulates cellular iron homeostasis and is correlated with the rate of cell proliferation [77]. TfR1 is directly regulated by hypoxia signaling and c-myc [77-79]. TfR1 overexpression in human tumors confers a growth advantage to cells and greatly enhances the rate of c-myc-mediated tumorigenesis, whereas its inhibition greatly decreases cellular proliferation and results in G1 arrest [80]. Increased TfR1 tumor cell surface expression is correlated to increased malignancy and thus may provide prognostic information for malignant tumors [81,82]. A second transferrin receptor TfR2 was recently cloned [83] that plays a key role in the regulation of iron homeostasis [84]. TfR2 is frequently expressed in various human cancer cell lines. In primary colon tumors, TfR2 was expressed in about $26 \%$ of CRC patients [85]. The expression of TfR2, together with increased TfR1, may represent a mechanism by which CRC cells accumulate iron.

\subsection{Ferritin}

Ferritin is a protein that regulates intracellular iron homeostasis by sequestering it within a hollow heteromultimer of heavy (H-ferritin) and light subunits (L-ferritin) [86]. Its ability to sequester the nutrient gives ferritin the dual functions of iron storage and iron detoxification [87]. As an indicator of iron storage, serum ferritin has a positive association with the formation of colorectal adenomatous polyps [88-90]. The elevated serum ferritin may be in part derived from the elevated ferritin content of colon neoplasms [91]. At the same time, as an intracellular iron scavenger, CRC cells enriched in endogenous ferritin are resistant to oxidant-producing chemotherapeutic agents, and prolonged iron exposure further increases the overall content of ferritin in these cells [92]. On the contrary, the 
down-regulation of $\mathrm{H}$-ferritin by the proto-oncogene c-myc in cells can increase the availability of intracellular free iron, leading to oxidative stress, cell transformation and cell proliferation [93]. These data demonstrate a complex and biphasic role of ferritin in CRC, where in context-dependent manner low and high ferritin may be advantageous to tumor growth.

\section{4. $H E P H$}

HEPH is expressed at high levels throughout the small intestine and colon [94]. HEPH is critical for oxidation of $\mathrm{Fe}^{2+}$ to $\mathrm{Fe}^{3+}$ allowing efficient loading of diferric iron onto transferrin. Although no studies have directly assessed HEPH expression in CRC, mining publicly available CRC microarray datasets [95] found that HEPH was significantly decreased in CRC from three independent studies $[96,97]$. Moreover, HEPH is directly regulated by the homeobox transcription factor CDX2. In CRC cells, overexpression of CDX2 activation rapidly increases the expression of HEPH and results in suppressed intracellular iron, whereas CDX2 inhibition leads to lower HEPH expression. CDX2 and HEPH expression are well correlated in normal and tumor tissues [98], and CDX2 expression is downregulated in CRC.

\subsection{Hepcidin and FPN}

Hepcidin is not expressed in normal colon epithelium, but it is increased in CRC tissue with a repression of FPN [99]. Furthermore, urinary hepcidin expression is positively associated with increasing T-stage of CRC. Thus, increases in both tumor-produced and systemic hepcidin could lead to decreased tumor FPN levels and greater iron retention by the tumor.

\section{Oxidative Stress and CRC}

Iron is essential for all living organisms and serves as a cofactor for many proteins and enzymes participating in numerous biological and cellular processes such as energy metabolism, cellular respiration, oxygen transport, DNA synthesis and cell growth [100,101]. In addition, iron accumulation leads to a robust increase in reactive oxygen species (ROS) formation, which is a critical mechanism leading to increase in colon tumorigenesis. Increased cellular iron can lead to the formation of ROS through the Fenton and Haber-Weiss reaction by catalyzing the decomposition of hydrogen peroxide [102]. Increased oxidative stress is genotoxic and can lead to DNA damage and subsequent gene mutations important in the initiation of colon tumorigenesis [103]. Iron is a potent genotoxic mutagen in primary non-transformed colon cells, preneoplastic colon adenoma cells and human CRC cell lines [104-106]. Moreover oxidative stress can lead to lipid peroxidation, which is enhanced in colon tumors compared to normal colonic mucosa [107]. High dietary iron increases lipid peroxidation in the colon from both mice and rats [108-110]. Lipid peroxidation propagates the free radical reactions and facilitates the formation of DNA-adducts that may contribute to tumorigenesis [111]. Lastly, oxidative stress induces a pleiotropic effect in cancers and can regulate proliferation, apoptosis, mitochondrial metabolism, and inflammation (Figure 2). The involvement of iron-induced oxidative damage in CRC is further demonstrated by the fact that the antioxidant $N$-acetylcysteine (NAC) inhibits 
dietary iron-induced $\mathrm{CRC}$ progression and nitrotyrosine-positive cell number in a colitis-associated CRC model $[112,113]$.

Figure 2. Iron-mediated colorectal cancer (CRC) progression. Through increased iron acquisition by DMT-1 from the diet or holo-Tf-TfR1 from the circulation, and decreased iron export by hepcidin-mediated degradation of FPN or decreased FPN expression, iron accumulation in colon tumors leads to an increase in reactive oxygen species (ROS) production, oncogene activation, pro-inflammatory mediators and dysbosis which contribute to an increase in the growth of CRC.

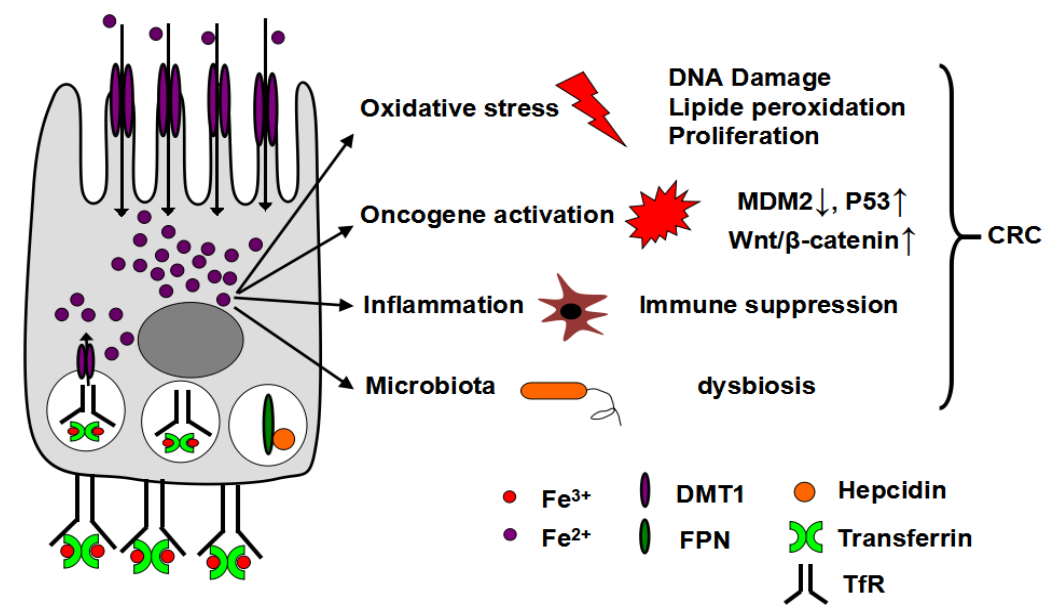

\section{Additional Pathways of Iron Induced-Tumorigenesis}

\subsection{Oncogene Activation}

Colorectal carcinogenesis is a multi-step process involving the formation of adenomatous polyps and their subsequent progression to malignancy. At the molecular level, this process is reflected by sequential events of gene mutation and activation of important molecular pathways [114]. Here we will discuss two key activated signaling pathways critical in CRC (Figure 2): (i) The ubiquitination and degradation of the tumor suppressor gene $\mathrm{p} 53$; and (ii) $\mathrm{Wnt} / \beta$-catenin signaling. Iron downregulates whereas iron chelator deferoxamine (DFO) upregulates the expression of mouse double minute gene 2 (MDM2), which is a ubiquitin ligase involved in the degradation of the p53 [115]. Iron overload-mediated reduction in MDM2 levels leads to p53 upregulation and consequent induction of antioxidant enzymes, thereby providing a mechanism to counteract iron-related oxidative stress. On the contrary, DFO causing moderate iron deficiency increases MDM2 level and consequently decreases p53 levels. Interestingly, DFO at toxic doses can also increase nuclear protein level and DNA-binding activity of $\mathrm{p} 53$, which causes the cell cycle arrest effects and anti-tumor activities [116,117]. Aberrant activation of $\mathrm{Wnt} / \beta$-catenin signaling contributes to the development of CRC [118]. The adenomatous polyposis coli $(A p c)$ gene, a key Wnt signaling factor for the regulation of mucosal epithelial maturation, is mutated in a majority of patients with familial, sporadic, and colitis-associated CRC [119-121]. APC mutations lead to nuclear accumulation of $\beta$-catenin and constitutive activation of the transcription factor T-cell factor/lymphoid enhancer factor (TCF/LEF), and results in activation of target genes, including cyclin D1 and c-myc, both of which are positive regulators of cell proliferation [122,123]. Iron 
can increase Wnt signaling following the loss of APC function [124], whereas iron chelators can block Wnt signaling and decrease the expression of cyclin D1 and c-myc to suppress cell growth $[101,125,126]$.

\subsection{Tumor Inflammatory Response}

Chronic inflammation is a major hallmark of CRC [127]. The relative risk for developing CRC in inflammatory bowel disease (IBD) patients is 11 times higher than that of the general population [128]. Moreover, sporadic colon tumors have a heightened inflammatory response without any preceding chronic inflammatory condition. The increase in pro-inflammatory response in tumors in general is thought to function as a growth supportive mechanism. Consistent with this notion there is strong evidence that anti-inflammatory drugs inhibit colon tumorigenesis, reduce the risk of CRC, and prevent the recurrence of adenomatous polyps [129]. In mouse models, dietary iron supplementation worsens dextran sodium sulfate-induced chronic inflammation and increases colorectal tumorigenesis, suggesting a tumor-promoting role of iron in the presence of inflammation [112]. The inflammatory microenvironment in tumors is highly complex, and not all tumoral inflammatory responses promote growth. The tumor immune response can also eliminate transformed cells. Currently, mechanisms that regulate the pro-tumorigenic versus the anti-tumorigenic balance of the tumor immune response are unclear. However, it is thought that immune suppression of effector cells is important in tipping the balance by which the tumor microenvironment promotes growth (Figure 2). A proposed mechanism by which iron in the tumor epithelium can result in immunosuppression is quenching the nitric oxide-mediated activation of NK cells [130]. Moreover, increased iron in macrophages leads to an attenuated inflammatory response by decreasing pro-inflammatory mediator production from macrophages [131-133].

\subsection{Iron and Microbiota}

The last 10 years has demonstrated the importance of the gut microbiota to health and disease. The intestinal lumen bacterial content is estimated to be an order of magnitude higher of number of cells than all of our somatic cells. The intestinal lumen is the most densely occupied microbial ecosystem found to date. Gnotobiotic mouse models and broad-spectrum antibiotic gut sterilization experiments have demonstrated the importance of the gut microbiota in CRC [134-138]. Accumulating evidence suggest that microbial dysbiosis is associated with the initiation and progression of CRC through disturbing mucosal immune response between host and microbiota [139-142] (Figure 2). The role of intestinal iron accumulation in gut dysbiosis and its implication in CRC has not been directly tested. However, several studies on rodent models and in humans have demonstrated that changes in dietary iron intake and luminal iron can have a profound influence in the gut microbiota [143-149]. Moreover, it has been hypothesized that the increase in CRC incidence in African American compared to native Africans is due to different compositions of intestinal microbiota between these two populations. A higher colonic population of potentially toxic hydrogen and secondary bile-salt-producing bacteria is observed in African Americans [150]. 


\section{Conclusions}

Systemic iron levels and local increase in iron accumulation in tumors significantly impacts the progression of CRC. Currently much more is known about modulating systemic iron levels and its role in $\mathrm{CRC}$ progression compared to intratumoral iron. Iron chelation therapy is efficacious in both animal studies and clinic settings. Furthermore, anti-TfR 1 antibodies exhibit antitumor activity through inhibiting iron uptake. However, systemic decrease of iron can exacerbate anemia that is present in most patients with CRC. The higher iron utilization by cancer cells than normal cells provides a rationale for reducing iron content in the colon to limit the progression of colon tumors. Further studies are required to understand the precise mechanism by which colon tumors accumulate iron and its role in CRC progression. DMT1 and TfR1 are both up-regulated in CRC, however no mechanistic study has been performed to understand if either DMT1 or TfR1 is essential for iron accumulation in CRC and its progression. These studies are complicated by the fact that disruption of their function in the intestine will cause systemic iron deficiency in mouse models. The future focus of iron restriction therapies in CRC will have to be on mechanisms that can specifically restrict iron in the colon, and the development of pharmacological methods to modulate colon iron could have the potential to impact human CRC.

\section{Acknowledgements}

This work was supported by NIH grants (CA148828 and DK095201) and The University of Michigan Gastrointestinal Peptide Center to Y.M.S.

\section{Conflicts of Interest}

The author declares no conflict of interest.

\section{References}

1. Siegel, R.; Naishadham, D.; Jemal, A. Cancer statistics. CA Cancer J. Clin. 2012, 62, 10-29.

2. Karim-Kos, H.E.; de Vries, E.; Soerjomataram, I.; Lemmens, V.; Siesling, S.; Coebergh, J.W. Recent trends of cancer in Europe: A combined approach of incidence, survival and mortality for 17 cancer sites since the 1990s. Eur. J. Cancer 2008, 44, 1345-1389.

3. Bray, F.; Sankila, R.; Ferlay, J.; Parkin, D.M. Estimates of cancer incidence and mortality in Europe in 1995. Eur. J. Cancer 2002, 38, 99-166.

4. Yasui, H.; Yoshino, T.; Boku, N.; Onozawa, Y.; Hironaka, S.; Fukutomi, A.; Yamazaki, K.; Taku, K.; Kojima, T.; Machida, N. Retrospective analysis of S-1 monotherapy in patients with metastatic colorectal cancer after failure to fluoropyrimidine and irinotecan or to fluoropyrimidine, irinotecan and oxaliplatin. Jpn. J. Clin. Oncol. 2009, 39, 315-320.

5. Fearon, E.R. Molecular genetics of colorectal cancer. Annu. Rev. Pathol. 2011, 6, 479-507.

6. Qiao, L.; Feng, Y. Intakes of heme iron and zinc and colorectal cancer incidence: A meta-analysis of prospective studies. Cancer Causes Control 2013, 24, 1175-1183.

7. Andrews, N.C.; Schmidt, P.J. Iron homeostasis. Annu. Rev. Physiol. 2007, 69, 69-85.

8. Han, O.; Failla, M.L.; Hill, A.D.; Morris, E.R.; Smith, J.C., Jr. Reduction of Fe(III) is required for uptake of nonheme iron by Caco-2 cells. J. Nutr. 1995, 125, 1291-1299. 
9. Ma, Q.; Kim, E.Y.; Han, O. Bioactive dietary polyphenols decrease heme iron absorption by decreasing basolateral iron release in human intestinal Caco-2 cells. J. Nutr. 2010, 140, 1117-1121.

10. Roughead, Z.K.; Zito, C.A.; Hunt, J.R. Inhibitory effects of dietary calcium on the initial uptake and subsequent retention of heme and nonheme iron in humans: Comparisons using an intestinal lavage method. Am. J. Clin. Nutr. 2005, 82, 589-597.

11. Theil, E.C. Iron homeostasis and nutritional iron deficiency. J. Nutr. 2011, 141, 724S-728S.

12. Shayeghi, M.; Latunde-Dada, G.O.; Oakhill, J.S.; Laftah, A.H.; Takeuchi, K.; Halliday, N.; Khan, Y.; Warley, A.; McCann, F.E.; Hider, R.C.; et al. Identification of an intestinal heme transporter. Cell 2005, 122, 789-801.

13. Qiu, A.; Jansen, M.; Sakaris, A.; Min, S.H.; Chattopadhyay, S.; Tsai, E.; Sandoval, C.; Zhao, R.; Akabas, M.H.; Goldman, I.D. Identification of an intestinal folate transporter and the molecular basis for hereditary folate malabsorption. Cell 2006, 127, 917-928.

14. Raffia, S.B.; Woo, C.H.; Roost, K.T.; Price, D.C.; Schmid, R. Intestinal absorption of hemoglobin iron-heme cleavage by mucosal heme oxygenase. J. Clin. Investig. 1974, 54, 1344-1352.

15. McKie, A.T.; Barrow, D.; Latunde-Dada, G.O.; Rolfs, A.; Sager, G.; Mudaly, E.; Mudaly, M.; Richardson, C.; Barlow, D.; Bomford, A.; et al. An iron-regulated ferric reductase associated with the absorption of dietary iron. Science 2001, 291, 1755-1759.

16. Gunshin, H.; Mackenzie, B.; Berger, U.V.; Gunshin, Y.; Romero, M.F.; Boron, W.F.; Nussberger, S.; Gollan, J.L.; Hediger, M.A. Cloning and characterization of a mammalian proton-coupled metal-ion transporter. Nature 1997, 388, 482-488.

17. Gunshin, H.; Fujiwara, Y.; Custodio, A.O.; Direnzo, C.; Robine, S.; Andrews, N.C. Slc11a2 is required for intestinal iron absorption and erythropoiesis but dispensable in placenta and liver. J. Clin. Investig. 2005, 115, 1258-1266.

18. Theil, E.C. Ferritin: At the crossroads of iron and oxygen metabolism. J. Nutr. 2003, 133, 1549S-1553S.

19. Donovan, A.; Brownlie, A.; Zhou, Y.; Shepard, J.; Pratt, S.J.; Moynihan, J.; Paw, B.H.; Drejer, A.; Barut, B.; Zapata, A.; et al. Positional cloning of zebrafish ferroportin1 identifies a conserved vertebrate iron exporter. Nature 2000, 403, 776-781.

20. McKie, A.T.; Marciani, P.; Rolfs, A.; Brennan, K.; Wehr, K.; Barrow, D.; Miret, S.; Bomford, A.; Peters, T.J.; Farzaneh, F.; et al. A novel duodenal iron-regulated transporter, IREG1, implicated in the basolateral transfer of iron to the circulation. Mol. Cell 2000, 5, 299-309.

21. Hahn, P.; Qian, Y.; Dentchev, T.; Chen, L.; Beard, J.; Harris, Z.L.; Dunaief, J.L. Disruption of ceruloplasmin and hephaestin in mice causes retinal iron overload and retinal degeneration with features of age-related macular degeneration. Proc. Natl. Acad. Sci. USA 2004, 101, 13850-13855.

22. Cherukuri, S.; Potla, R.; Sarkar, J.; Nurko, S.; Harris, Z.L.; Fox, P.L. Unexpected role of ceruloplasmin in intestinal iron absorption. Cell Metab. 2005, 2, 309-319.

23. Vulpe, C.D.; Kuo, Y.M.; Murphy, T.L.; Cowley, L.; Askwith, C.; Libina, N.; Gitschier, J.; Anderson, G.J. Hephaestin, a ceruloplasmin homologue implicated in intestinal iron transport, is defective in the sla mouse. Nat. Genet. 1999, 21, 195-199.

24. Laurell, C.B. What is the function of transferrin in plasma? Blood 1951, 6, 183-187.

25. Hentze, M.W.; Muckenthaler, M.U.; Andrews, N.C. Balancing acts: Molecular control of mammalian iron metabolism. Cell 2004, 117, 285-297. 
26. Gatter, K.C.; Brown, G.; Trowbridge, I.S.; Woolston, R.E.; Mason, D.Y. Transferrin receptors in human tissues: Their distribution and possible clinical relevance. J. Clin. Pathol. 1983, 36, $539-545$.

27. Blachier, F.; Vaugelade, P.; Robert, V.; Kibangou, B.; Canonne-Hergaux, F.; Delpal, S.; Bureau, F.; Blottiere, H.; Bougle, D. Comparative capacities of the pig colon and duodenum for luminal iron absorption. Can. J. Physiol. Pharmacol. 2007, 85, 185-192.

28. Tako, E.; Glahn, R.P.; Welch, R.M.; Lei, X.; Yasuda, K.; Miller, D.D. Dietary inulin affects the expression of intestinal enterocyte iron transporters, receptors and storage protein and alters the microbiota in the pig intestine. Br. J. Nutr. 2008, 99, 472-480.

29. Mole, D.R. Iron homeostasis and its interaction with prolyl hydroxylases. Antioxid. Redox. Signal. 2010, 12, 445-458.

30. Simpson, R.J.; McKie, A.T. Regulation of intestinal iron absorption: The mucosa takes control? Cell Metab. 2009, 10, 84-87.

31. Ganz, T.; Nemeth, E. Hepcidin and iron homeostasis. Biochim. Biophys. Acta 2012, 1823, 1434-1443.

32. Ganz, T.; Nemeth, E. Hepcidin and disorders of iron metabolism. Annu. Rev. Med. 2011, 62, $347-360$.

33. Knutson, M.D. Iron-sensing proteins that regulate hepcidin and enteric iron absorption. Annu. Rev. Nutr. 2010, 30, 149-171.

34. Eisenstein, R.S. Iron regulatory proteins and the molecular control of mammalian iron metabolism. Annu. Rev. Nutr. 2000, 20, 627-662.

35. Pigeon, C.; Ilyin, G.; Courselaud, B.; Leroyer, P.; Turlin, B.; Brissot, P.; Loreal, O. A new mouse liver-specific gene, encoding a protein homologous to human antimicrobial peptide hepcidin, is overexpressed during iron overload. J. Biol. Chem. 2001, 276, 7811-7819.

36. Lesbordes-Brion, J.C.; Viatte, L.; Bennoun, M.; Lou, D.Q.; Ramey, G.; Houbron, C.; Hamard, G.; Kahn, A.; Vaulont, S. Targeted disruption of the hepcidin 1 gene results in severe hemochromatosis. Blood 2006, 108, 1402-1405.

37. Nemeth, E.; Tuttle, M.S.; Powelson, J.; Vaughn, M.B.; Donovan, A.; Ward, D.M.; Ganz, T.; Kaplan, J. Hepcidin regulates cellular iron efflux by binding to ferroportin and inducing its internalization. Science 2004, 306, 2090-2093.

38. Chua, A.C.; Klopcic, B.; Lawrance, I.C.; Olynyk, J.K.; Trinder, D. Iron: An emerging factor in colorectal carcinogenesis. World J. Gastroenterol. 2010, 16, 663-672.

39. Nelson, R.L. Iron and colorectal cancer risk: Human studies. Nutr. Rev. 2001, 59, 140-148.

40. Chan, A.T.; Ma, J.; Tranah, G.J.; Giovannucci, E.L.; Rifai, N.; Hunter, D.J.; Fuchs, C.S. Hemochromatosis gene mutations, body iron stores, dietary iron, and risk of colorectal adenoma in women. J. Natl. Cancer Inst. 2005, 97, 917-926.

41. Bridle, K.R.; Frazer, D.M.; Wilkins, S.J.; Dixon, J.L.; Purdie, D.M.; Crawford, D.H.; Subramaniam, V.N.; Powell, L.W.; Anderson, G.J.; Ramm, G.A. Disrupted hepcidin regulation in HFE-associated haemochromatosis and the liver as a regulator of body iron homoeostasis. Lancet 2003, 361, 669-673.

42. Schmidt, P.J.; Toudjarska, I.; Sendamarai, A.K.; Racie, T.; Milstein, S.; Bettencourt, B.R.; Hettinger, J.; Bumcrot, D.; Fleming, M.D. An RNAi therapeutic targeting Tmprss6 decreases iron 
overload in $\mathrm{Hfe}(-/-)$ mice and ameliorates anemia and iron overload in murine beta-thalassemia intermedia. Blood 2013, 121, 1200-1208.

43. Osborne, N.J.; Gurrin, L.C.; Allen, K.J.; Constantine, C.C.; Delatycki, M.B.; McLaren, C.E.; Gertig, D.M.; Anderson, G.J.; Southey, M.C.; Olynyk, J.K.; et al. HFE C282Y homozygotes are at increased risk of breast and colorectal cancer. Hepatology 2010, 51, 1311-1318.

44. Shi, Z.; Johnstone, D.; Talseth-Palmer, B.A.; Evans, T.J.; Spigelman, A.D.; Groombridge, C.; Milward, E.A.; Olynyk, J.K.; Suchy, J.; Kurzawski, G.; et al. Haemochromatosis HFE gene polymorphisms as potential modifiers of hereditary nonpolyposis colorectal cancer risk and onset age. Int. J. Cancer 2009, 125, 78-83.

45. Shaheen, N.J.; Silverman, L.M.; Keku, T.; Lawrence, L.B.; Rohlfs, E.M.; Martin, C.F.; Galanko, J.; Sandler, R.S. Association between hemochromatosis (HFE) gene mutation carrier status and the risk of colon cancer. J. Natl. Cancer Inst. 2003, 95, 154-159.

46. Aune, D.; Chan, D.S.; Vieira, A.R.; Navarro Rosenblatt, D.A.; Vieira, R.; Greenwood, D.C.; Kampman, E.; Norat, T. Red and processed meat intake and risk of colorectal adenomas: A systematic review and meta-analysis of epidemiological studies. Cancer Causes Control 2013, 24, 611-627.

47. Norat, T.; Bingham, S.; Ferrari, P.; Slimani, N.; Jenab, M.; Mazuir, M.; Overvad, K.; Olsen, A.; Tjonneland, A.; Clavel, F.; et al. Meat, fish, and colorectal cancer risk: The European Prospective Investigation into cancer and nutrition. J. Natl. Cancer Inst. 2005, 97, 906-916.

48. Cross, A.J.; Ferrucci, L.M.; Risch, A.; Graubard, B.I.; Ward, M.H.; Park, Y.; Hollenbeck, A.R.; Schatzkin, A.; Sinha, R. A large prospective study of meat consumption and colorectal cancer risk: An investigation of potential mechanisms underlying this association. Cancer Res. 2010, 70, 2406-2414.

49. Sesink, A.L.; Termont, D.S.; Kleibeuker, J.H.; van der Meer, R. Red meat and colon cancer: Dietary haem, but not fat, has cytotoxic and hyperproliferative effects on rat colonic epithelium. Carcinogenesis 2000, 21, 1909-1915.

50. Sesink, A.L.; Termont, D.S.; Kleibeuker, J.H.; van der Meer, R. Red meat and colon cancer: The cytotoxic and hyperproliferative effects of dietary heme. Cancer Res. 1999, 59, 5704-5709.

51. Noortje, I.J.; Rijnierse, A.; de Wit, N.; Jonker-Termont, D.; Dekker, J.; Muller, M.; van der Meer, R. Dietary haem stimulates epithelial cell turnover by downregulating feedback inhibitors of proliferation in murine colon. Gut 2012, 61, 1041-1049.

52. Bastide, N.M.; Pierre, F.H.; Corpet, D.E. Heme iron from meat and risk of colorectal cancer: A meta-analysis and a review of the mechanisms involved. Cancer Prev. Res. (Phila.) 2011, 4, 177-184.

53. Joosen, A.M.; Kuhnle, G.G.; Aspinall, S.M.; Barrow, T.M.; Lecommandeur, E.; Azqueta, A.; Collins, A.R.; Bingham, S.A. Effect of processed and red meat on endogenous nitrosation and DNA damage. Carcinogenesis 2009, 30, 1402-1407.

54. Baradat, M.; Jouanin, I.; Dalleau, S.; Tache, S.; Gieules, M.; Debrauwer, L.; Canlet, C.; Huc, L.; Dupuy, J.; Pierre, F.H.; et al. 4-Hydroxy-2(E)-nonenal metabolism differs in Apc(+/+) cells and in Apc(Min/+) cells: It may explain colon cancer promotion by heme iron. Chem. Res. Toxicol. 2011, 24, 1984-1993. 
55. Corpet, D.E. Red meat and colon cancer: Should we become vegetarians, or can we make meat safer? Meat Sci. 2011, 89, 310-316.

56. Pierre, F.; Santarelli, R.; Tache, S.; Gueraud, F.; Corpet, D.E. Beef meat promotion of dimethylhydrazine-induced colorectal carcinogenesis biomarkers is suppressed by dietary calcium. Br. J. Nutr. 2008, 99, 1000-1006.

57. Balder, H.F.; Vogel, J.; Jansen, M.C.; Weijenberg, M.P.; van den Brandt, P.A.; Westenbrink, S.; van der Meer, R.; Goldbohm, R.A. Heme and chlorophyll intake and risk of colorectal cancer in the Netherlands cohort study. Cancer Epidemiol. Biomarkers Prev. 2006, 15, 717-725.

58. De Vogel, J.; Jonker-Termont, D.S.; van Lieshout, E.M.; Katan, M.B.; van der Meer, R. Green vegetables, red meat and colon cancer: Chlorophyll prevents the cytotoxic and hyperproliferative effects of haem in rat colon. Carcinogenesis 2005, 26, 387-393.

59. Lee, D.H.; Jacobs, D.R., Jr.; Folsom, A.R. A hypothesis: Interaction between supplemental iron intake and fermentation affecting the risk of colon cancer. The Iowa Women's Health Study. Nutr. Cancer 2004, 48, 1-5.

60. Lund, E.K.; Wharf, S.G.; Fairweather-Tait, S.J.; Johnson, I.T. Oral ferrous sulfate supplements increase the free radical-generating capacity of feces from healthy volunteers. Am. J. Clin. Nutr. 1999, 69, 250-255.

61. Rosenberg, D.W.; Giardina, C.; Tanaka, T. Mouse models for the study of colon carcinogenesis. Carcinogenesis 2009, 30, 183-196.

62. Siegers, C.P.; Bumann, D.; Baretton, G.; Younes, M. Dietary iron enhances the tumor rate in dimethylhydrazine-induced colon carcinogenesis in mice. Cancer Lett. 1988, 41, 251-256.

63. Radulescu, S.; Brookes, M.J.; Salgueiro, P.; Ridgway, R.A.; McGhee, E.; Anderson, K.; Ford, S.J.; Stones, D.H.; Iqbal, T.H.; Tselepis, C.; et al. Luminal iron levels govern intestinal tumorigenesis after Apc loss in vivo. Cell Rep. 2012, 2, 270-282.

64. Xue, X.; Taylor, M.; Anderson, E.; Hao, C.; Qu, A.; Greenson, J.K.; Zimmermann, E.M.; Gonzalez, F.J.; Shah, Y.M. Hypoxia-inducible factor- $2 \alpha$ activation promotes colorectal cancer progression by dysregulating iron homeostasis. Cancer Res. 2012, 72, 2285-2293.

65. Besarab, A.; Horl, W.H.; Silverberg, D. Iron metabolism, iron deficiency, thrombocytosis, and the cardiorenal anemia syndrome. Oncologist 2009, 14, 22-33.

66. Merk, K.; Mattsson, B.; Mattsson, A.; Holm, G.; Gullbring, B.; Bjorkholm, M. The incidence of cancer among blood donors. Int. J. Epidemiol. 1990, 19, 505-509.

67. Zacharski, L.R.; Chow, B.K.; Howes, P.S.; Shamayeva, G.; Baron, J.A.; Dalman, R.L.; Malenka, D.J.; Ozaki, C.K.; Lavori, P.W. Decreased cancer risk after iron reduction in patients with peripheral arterial disease: Results from a randomized trial. J. Natl. Cancer Inst. 2008, 100, 996-1002.

68. Brookes, M.J.; Hughes, S.; Turner, F.E.; Reynolds, G.; Sharma, N.; Ismail, T.; Berx, G.; McKie, A.T.; Hotchin, N.; Anderson, G.J.; et al. Modulation of iron transport proteins in human colorectal carcinogenesis. Gut 2006, 55, 1449-1460.

69. Jiang, X.P.; Elliott, R.L.; Head, J.F. Manipulation of iron transporter genes results in the suppression of human and mouse mammary adenocarcinomas. Anticancer Res. 2010, 30, 759-765. 
70. Pinnix, Z.K.; Miller, L.D.; Wang, W.; D’Agostino, R., Jr.; Kute, T.; Willingham, M.C.; Hatcher, H.; Tesfay, L.; Sui, G.; Di, X.; et al. Ferroportin and iron regulation in breast cancer progression and prognosis. Sci. Transl. Med. 2010, 2, 43ra56, doi:10.1126/scisignal.3001127.

71. Takeuchi, K.; Bjarnason, I.; Laftah, A.H.; Latunde-Dada, G.O.; Simpson, R.J.; McKie, A.T. Expression of iron absorption genes in mouse large intestine. Scand. J. Gastroenterol. 2005, 40, 169-177.

72. Zou, T.T.; Selaru, F.M.; Xu, Y.; Shustova, V.; Yin, J.; Mori, Y.; Shibata, D.; Sato, F.; Wang, S.; Olaru, A.; et al. Application of cDNA microarrays to generate a molecular taxonomy capable of distinguishing between colon cancer and normal colon. Oncogene 2002, 21, 4855-4862.

73. Skrzypczak, M.; Goryca, K.; Rubel, T.; Paziewska, A.; Mikula, M.; Jarosz, D.; Pachlewski, J.; Oledzki, J.; Ostrowski, J. Modeling oncogenic signaling in colon tumors by multidirectional analyses of microarray data directed for maximization of analytical reliability. PLoS One 2010, 5, e13091.

74. Sabates-Bellver, J.; van der Flier, L.G.; de Palo, M.; Cattaneo, E.; Maake, C.; Rehrauer, H.; Laczko, E.; Kurowski, M.A.; Bujnicki, J.M.; Menigatti, M.; et al. Transcriptome profile of human colorectal adenomas. Mol. Cancer Res. 2007, 5, 1263-1275.

75. Knekt, P.; Reunanen, A.; Takkunen, H.; Aromaa, A.; Heliovaara, M.; Hakulinen, T. Body iron stores and risk of cancer. Int. J. Cancer 1994, 56, 379-382.

76. Prutki, M.; Poljak-Blazi, M.; Jakopovic, M.; Tomas, D.; Stipancic, I.; Zarkovic, N. Altered iron metabolism, transferrin receptor 1 and ferritin in patients with colon cancer. Cancer Lett. 2006, $238,188-196$.

77. Okazaki, F.; Matsunaga, N.; Okazaki, H.; Utoguchi, N.; Suzuki, R.; Maruyama, K.; Koyanagi, S.; Ohdo, S. Circadian rhythm of transferrin receptor 1 gene expression controlled by c-Myc in colon cancer-bearing mice. Cancer Res. 2010, 70, 6238-6246.

78. Tacchini, L.; Bianchi, L.; Bernelli-Zazzera, A.; Cairo, G. Transferrin receptor induction by hypoxia. HIF-1-mediated transcriptional activation and cell-specific post-transcriptional regulation. J. Biol. Chem. 1999, 274, 24142-24146.

79. Lok, C.N.; Ponka, P. Identification of a hypoxia response element in the transferrin receptor gene. J. Biol. Chem. 1999, 274, 24147-24152.

80. O’Donnell, K.A.; Yu, D.; Zeller, K.I.; Kim, J.W.; Racke, F.; Thomas-Tikhonenko, A.; Dang, C.V. Activation of transferrin receptor 1 by c-Myc enhances cellular proliferation and tumorigenesis. Mol. Cell. Biol. 2006, 26, 2373-2386.

81. Habeshaw, J.A.; Lister, T.A.; Stansfeld, A.G.; Greaves, M.F. Correlation of transferrin receptor expression with histological class and outcome in non-Hodgkin lymphoma. Lancet 1983, 1 , 498-501.

82. Wrba, F.; Ritzinger, E.; Reiner, A.; Holzner, J.H. Transferrin receptor (TrfR) expression in breast carcinoma and its possible relationship to prognosis. An immunohistochemical study. Virchows Arch. A 1986, 410, 69-73.

83. Kawabata, H.; Yang, R.; Hirama, T.; Vuong, P.T.; Kawano, S.; Gombart, A.F.; Koeffler, H.P. Molecular cloning of transferrin receptor 2. A new member of the transferrin receptor-like family. J. Biol. Chem. 1999, 274, 20826-20832. 
84. Calzolari, A.; Oliviero, I.; Deaglio, S.; Mariani, G.; Biffoni, M.; Sposi, N.M.; Malavasi, F.; Peschle, C.; Testa, U. Transferrin receptor 2 is frequently expressed in human cancer cell lines. Blood Cells Mol. Dis. 2007, 39, 82-91.

85. Calzolari, A.; Deaglio, S.; Maldi, E.; Cassoni, P.; Malavasi, F.; Testa, U. TfR2 expression in human colon carcinomas. Blood Cells Mol. Dis. 2009, 43, 243-249.

86. Andrews, N.C. Ferrit(in)ing out new mechanisms in iron homeostasis. Cell Metab. 2010, 12, 203-204.

87. Harrison, P.M.; Arosio, P. The ferritins: Molecular properties, iron storage function and cellular regulation. Biochim. Biophys. Acta 1996, 1275, 161-203.

88. Nelson, R.L.; Davis, F.G.; Sutter, E.; Sobin, L.H.; Kikendall, J.W.; Bowen, P. Body iron stores and risk of colonic neoplasia. J. Natl. Cancer Inst. 1994, 86, 455-460.

89. Bird, C.L.; Witte, J.S.; Swendseid, M.E.; Shikany, J.M.; Hunt, I.F.; Frank1, H.D.; Lee, E.R.; Longnecker, M.P.; Haile, R.W. Plasma ferritin, iron intake, and the risk of colorectal polyps. Am. J. Epidemiol. 1996, 144, 34-41.

90. Tseng, M.; Greenberg, E.R.; Sandler, R.S.; Baron, J.A.; Haile, R.W.; Blumberg, B.S.; McGlynn, K.A. Serum ferritin concentration and recurrence of colorectal adenoma. Cancer Epidemiol. Biomarkers Prev. 2000, 9, 625-630.

91. Vaughn, C.B.; Weinstein, R.; Bond, B.; Rice, R.; Vaughn, R.W.; McKendrick, A.; Ayad, G.; Rockwell, M.A.; Rocchio, R. Ferritin content in human cancerous and noncancerous colonic tissue. Cancer Investig. 1987, 5, 7-10.

92. Cermak, J.; Balla, J.; Jacob, H.S.; Balla, G.; Enright, H.; Nath, K.; Vercellotti, G.M. Tumor cell heme uptake induces ferritin synthesis resulting in altered oxidant sensitivity: Possible role in chemotherapy efficacy. Cancer Res. 1993, 53, 5308-5313.

93. Wu, K.J.; Polack, A.; Dalla-Favera, R. Coordinated regulation of iron-controlling genes, H-ferritin and IRP2, by c-MYC. Science 1999, 283, 676-679.

94. Frazer, D.M.; Vulpe, C.D.; McKie, A.T.; Wilkins, S.J.; Trinder, D.; Cleghorn, G.J.; Anderson, G.J. Cloning and gastrointestinal expression of rat hephaestin: Relationship to other iron transport proteins. Am. J. Physiol. Gastrointest. Liver Physiol. 2001, 281, G931-G939.

95. Rhodes, D.R.; Chinnaiyan, A.M. Integrative analysis of the cancer transcriptome. Nat. Genet. 2005, 37, S31-S37.

96. Gaedcke, J.; Grade, M.; Jung, K.; Camps, J.; Jo, P.; Emons, G.; Gehoff, A.; Sax, U.; Schirmer, M.; Becker, H.; et al. Mutated KRAS results in overexpression of DUSP4, a MAP-kinase phosphatase, and SMYD3, a histone methyltransferase, in rectal carcinomas. Genes Chromosomes Cancer 2010, 49, 1024-1034.

97. Hong, Y.; Downey, T.; Eu, K.W.; Koh, P.K.; Cheah, P.Y. A “metastasis-prone” signature for early-stage mismatch-repair proficient sporadic colorectal cancer patients and its implications for possible therapeutics. Clin. Exp. Metastasis 2010, 27, 83-90.

98. Hinoi, T.; Gesina, G.; Akyol, A.; Kuick, R.; Hanash, S.; Giordano, T.J.; Gruber, S.B.; Fearon, E.R. CDX2-regulated expression of iron transport protein hephaestin in intestinal and colonic epithelium. Gastroenterology 2005, 128, 946-961. 
99. Ward, D.G.; Roberts, K.; Brookes, M.J.; Joy, H.; Martin, A.; Ismail, T.; Spychal, R.; Iqbal, T.; Tselepis, C. Increased hepcidin expression in colorectal carcinogenesis. World. J. Gastroenterol. 2008, 14, 1339-1345.

100. Pantopoulos, K.; Porwal, S.K.; Tartakoff, A.; Devireddy, L. Mechanisms of mammalian iron homeostasis. Biochemistry 2012, 51, 5705-5724.

101. Le, N.T.; Richardson, D.R. The role of iron in cell cycle progression and the proliferation of neoplastic cells. Biochim. Biophys. Acta 2002, 1603, 31-46.

102. Jomova, K.; Valko, M. Importance of iron chelation in free radical-induced oxidative stress and human disease. Curr. Pharm. Des. 2011, 17, 3460-3473.

103. Ribeiro, M.L.; Priolli, D.G.; Miranda, D.D.; Arcari, D.P.; Pedrazzoli, J., Jr.; Martinez, C.A. Analysis of oxidative DNA damage in patients with colorectal cancer. Clin. Colorectal Cancer 2008, 7, 267-272.

104. Knobel, Y.; Weise, A.; Glei, M.; Sendt, W.; Claussen, U.; Pool-Zobel, B.L. Ferric iron is genotoxic in non-transformed and preneoplastic human colon cells. Food Chem. Toxicol. 2007, 45, 804-811.

105. Glei, M.; Latunde-Dada, G.O.; Klinder, A.; Becker, T.W.; Hermann, U.; Voigt, K.; Pool-Zobel, B.L. Iron-overload induces oxidative DNA damage in the human colon carcinoma cell line HT29 clone 19A. Mutat. Res. 2002, 519, 151-161.

106. Nunez, M.T.; Tapia, V.; Toyokuni, S.; Okada, S. Iron-induced oxidative damage in colon carcinoma (Caco-2) cells. Free Radic. Res. 2001, 34, 57-68.

107. Rainis, T.; Maor, I.; Lanir, A.; Shnizer, S.; Lavy, A. Enhanced oxidative stress and leucocyte activation in neoplastic tissues of the colon. Dig. Dis. Sci. 2007, 52, 526-530.

108. Younes, M.; Trepkau, H.D.; Siegers, C.P. Enhancement by dietary iron of lipid peroxidation in mouse colon. Res. Commun. Chem. Pathol. Pharmacol. 1990, 70, 349-354.

109. Stone, W.L.; Papas, A.M.; LeClair, I.O.; Qui, M.; Ponder, T. The influence of dietary iron and tocopherols on oxidative stress and ras-p21 levels in the colon. Cancer Detect. Prev. 2002, 26, 78-84.

110. Lund, E.K.; Fairweather-Tait, S.J.; Wharf, S.G.; Johnson, I.T. Chronic exposure to high levels of dietary iron fortification increases lipid peroxidation in the mucosa of the rat large intestine. J. Nutr. 2001, 131, 2928-2931.

111. Marnett, L.J. Lipid peroxidation-DNA damage by malondialdehyde. Mutat. Res. 1999, 424, 83-95.

112. Seril, D.N.; Liao, J.; Ho, K.L.; Warsi, A.; Yang, C.S.; Yang, G.Y. Dietary iron supplementation enhances DSS-induced colitis and associated colorectal carcinoma development in mice. Dig. Dis. Sci. 2002, 47, 1266-1278.

113. Seril, D.N.; Liao, J.; Ho, K.L.; Yang, C.S.; Yang, G.Y. Inhibition of chronic ulcerative colitis-associated colorectal adenocarcinoma development in a murine model by $\mathrm{N}$-acetylcysteine. Carcinogenesis 2002, 23, 993-1001.

114. Kinzler, K.W.; Vogelstein, B. Lessons from hereditary colorectal cancer. Cell 1996, 87, 159-170.

115. Dongiovanni, P.; Fracanzani, A.L.; Cairo, G.; Megazzini, C.P.; Gatti, S.; Rametta, R.; Fargion, S.; Valenti, L. Iron-dependent regulation of MDM2 influences p53 activity and hepatic carcinogenesis. Am. J. Pathol. 2010, 176, 1006-1017. 
116. Fukuchi, K.; Tomoyasu, S.; Watanabe, H.; Kaetsu, S.; Tsuruoka, N.; Gomi, K. Iron deprivation results in an increase in p53 expression. Biol. Chem. Hoppe Seyler. 1995, 376, 627-630.

117. Liang, S.X.; Richardson, D.R. The effect of potent iron chelators on the regulation of p53: Examination of the expression, localization and DNA-binding activity of p53 and the transactivation of WAF1. Carcinogenesis 2003, 24, 1601-1614.

118. Reya, T.; Clevers, H. Wnt signalling in stem cells and cancer. Nature 2005, 434, 843-850.

119. Nishisho, I.; Nakamura, Y.; Miyoshi, Y.; Miki, Y.; Ando, H.; Horii, A.; Koyama, K.; Utsunomiya, J.; Baba, S.; Hedge, P. Mutations of chromosome $5 \mathrm{q} 21$ genes in FAP and colorectal cancer patients. Science 1991, 253, 665-669.

120. Bodmer, W.F.; Bailey, C.J.; Bodmer, J.; Bussey, H.J.; Ellis, A.; Gorman, P.; Lucibello, F.C.; Murday, V.A.; Rider, S.H.; Scambler, P.; et al. Localization of the gene for familial adenomatous polyposis on chromosome 5. Nature 1987, 328, 614-616.

121. Leppert, M.; Dobbs, M.; Scambler, P.; O’Connell, P.; Nakamura, Y.; Stauffer, D.; Woodward, S.; Burt, R.; Hughes, J.; Gardner, E.; et al. The gene for familial polyposis coli maps to the long arm of chromosome 5. Science 1987, 238, 1411-1413.

122. He, T.C.; Sparks, A.B.; Rago, C.; Hermeking, H.; Zawel, L.; da Costa, L.T.; Morin, P.J.; Vogelstein, B.; Kinzler, K.W. Identification of c-MYC as a target of the APC pathway. Science 1998, 281, 1509-1512.

123. Tetsu, O.; McCormick, F. Beta-catenin regulates expression of cyclin D1 in colon carcinoma cells. Nature 1999, 398, 422-426.

124. Brookes, M.J.; Boult, J.; Roberts, K.; Cooper, B.T.; Hotchin, N.A.; Matthews, G.; Iqbal, T.; Tselepis, C. A role for iron in Wnt signalling. Oncogene 2008, 27, 966-975.

125. Song, S.; Christova, T.; Perusini, S.; Alizadeh, S.; Bao, R.Y.; Miller, B.W.; Hurren, R.; Jitkova, Y.; Gronda, M.; Isaac, M.; et al. Wnt inhibitor screen reveals iron dependence of beta-catenin signaling in cancers. Cancer Res. 2011, 71, 7628-7639.

126. Coombs, G.S.; Schmitt, A.A.; Canning, C.A.; Alok, A.; Low, I.C.; Banerjee, N.; Kaur, S.; Utomo, V.; Jones, C.M.; Pervaiz, S.; et al. Modulation of Wnt/beta-catenin signaling and proliferation by a ferrous iron chelator with therapeutic efficacy in genetically engineered mouse models of cancer. Oncogene 2012, 31, 213-225.

127. Hanahan, D.; Weinberg, R.A. Hallmarks of cancer: The next generation. Cell 2011, 144, 646-674.

128. Prior, P.; Gyde, S.N.; Macartney, J.C.; Thompson, H.; Waterhouse, J.A.; Allan, R.N. Cancer morbidity in ulcerative colitis. Gut 1982, 23, 490-497.

129. Wang, D.; DuBois, R.N. The role of anti-inflammatory drugs in colorectal cancer. Annu. Rev. Med. 2013, 64, 131-144.

130. Elliott, R.L. Cancer immunothearapy more than vaccines "psychoneuro-immunooncology: Cancer, the host, and the surgeon". J. Cancer Ther. 2011, 2, 401-407.

131. Wang, L.; Harrington, L.; Trebicka, E.; Shi, H.N.; Kagan, J.C.; Hong, C.C.; Lin, H.Y.; Babitt, J.L.; Cherayil, B.J. Selective modulation of TLR4-activated inflammatory responses by altered iron homeostasis in mice. J. Clin. Investig. 2009, 119, 3322-3328.

132. Zhang, F.; Tao, Y.; Zhang, Z.; Guo, X.; An, P.; Shen, Y.; Wu, Q.; Yu, Y.; Wang, F. Metalloreductase Steap3 coordinates the regulation of iron homeostasis and inflammatory responses. Haematologica 2012, 97, 1826-1835. 
133. Zhang, Z.; Zhang, F.; An, P.; Guo, X.; Shen, Y.; Tao, Y.; Wu, Q.; Zhang, Y.; Yu, Y.; Ning, B.; et al. Ferroportin1 deficiency in mouse macrophages impairs iron homeostasis and inflammatory responses. Blood 2011, 118, 1912-1922.

134. Klimesova, K.; Kverka, M.; Zakostelska, Z.; Hudcovic, T.; Hrncir, T.; Stepankova, R.; Rossmann, P.; Ridl, J.; Kostovcik, M.; Mrazek, J.; et al. Altered gut microbiota promotes colitis-associated cancer in IL-1 receptor-associated kinase M-deficient mice. Inflamm. Bowel Dis. 2013, 19, $1266-1277$.

135. Arthur, J.C.; Jobin, C. The complex interplay between inflammation, the microbiota and colorectal cancer. Gut Microbes 2013, 4, 253-258.

136. Zhu, Q.; Gao, R.; Wu, W.; Qin, H. The role of gut microbiota in the pathogenesis of colorectal cancer. Tumor Biol. 2013, 34, 1285-1300.

137. Engle, S.J.; Ormsby, I.; Pawlowski, S.; Boivin, G.P.; Croft, J.; Balish, E.; Doetschman, T. Elimination of colon cancer in germ-free transforming growth factor beta 1-deficient mice. Cancer Res. 2002, 62, 6362-6366.

138. Grivennikov, S.I.; Wang, K.; Mucida, D.; Stewart, C.A.; Schnabl, B.; Jauch, D.; Taniguchi, K.; Yu, G.Y.; Osterreicher, C.H.; Hung, K.E.; et al. Adenoma-linked barrier defects and microbial products drive IL-23/IL-17-mediated tumour growth. Nature 2012, 491, 254-258.

139. Sobhani, I.; Tap, J.; Roudot-Thoraval, F.; Roperch, J.P.; Letulle, S.; Langella, P.; Corthier, G.; Tran van Nhieu, J.; Furet, J.P. Microbial dysbiosis in colorectal cancer (CRC) patients. PLoS One 2011, 6, e16393.

140. Vipperla, K.; O'Keefe, S.J. The microbiota and its metabolites in colonic mucosal health and cancer risk. Nutr. Clin. Pract. 2012, 27, 624-635.

141. Marchesi, J.R.; Dutilh, B.E.; Hall, N.; Peters, W.H.; Roelofs, R.; Boleij, A.; Tjalsma, H. Towards the human colorectal cancer microbiome. PLoS One 2011, 6, e20447.

142. Kau, A.L.; Ahern, P.P.; Griffin, N.W.; Goodman, A.L.; Gordon, J.I. Human nutrition, the gut microbiome and the immune system. Nature 2011, 474, 327-336.

143. Dostal, A.; Fehlbaum, S.; Chassard, C.; Zimmermann, M.B.; Lacroix, C. Low iron availability in continuous in vitro colonic fermentations induces strong dysbiosis of the child gut microbial consortium and a decrease in main metabolites. FEMS Microbiol. Ecol. 2013, 83, 161-175.

144. Dostal, A.; Chassard, C.; Hilty, F.M.; Zimmermann, M.B.; Jaeggi, T.; Rossi, S.; Lacroix, C. Iron depletion and repletion with ferrous sulfate or electrolytic iron modifies the composition and metabolic activity of the gut microbiota in rats. J. Nutr. 2012, 142, 271-277.

145. Noortje, I.J.; Derrien, M.; van Doorn, G.M.; Rijnierse, A.; van den Bogert, B.; Muller, M.; Dekker, J.; Kleerebezem, M.; van der Meer, R. Dietary heme alters microbiota and mucosa of mouse colon without functional changes in host-microbe cross-talk. PLoS One 2012, 7, e49868.

146. Tompkins, G.R.; O’Dell, N.L.; Bryson, I.T.; Pennington, C.B. The effects of dietary ferric iron and iron deprivation on the bacterial composition of the mouse intestine. Curr. Microbiol. 2001, 43, $38-42$.

147. Buhnik-Rosenblau, K.; Moshe-Belizowski, S.; Danin-Poleg, Y.; Meyron-Holtz, E.G. Genetic modification of iron metabolism in mice affects the gut microbiota. Biometals 2012, 25, 883-892. 
148. Werner, T.; Wagner, S.J.; Martinez, I.; Walter, J.; Chang, J.S.; Clavel, T.; Kisling, S.; Schuemann, K.; Haller, D. Depletion of luminal iron alters the gut microbiota and prevents Crohn's disease-like ileitis. Gut 2011, 60, 325-333.

149. Zimmermann, M.B.; Chassard, C.; Rohner, F.; N'Goran, E.K.; Nindjin, C.; Dostal, A.; Utzinger, J.; Ghattas, H.; Lacroix, C.; Hurrell, R.F. The effects of iron fortification on the gut microbiota in African children: A randomized controlled trial in Cote d'Ivoire. Am. J. Clin. Nutr. 2010, 92, 1406-1415.

150. O’Keefe, S.J.; Chung, D.; Mahmoud, N.; Sepulveda, A.R.; Manafe, M.; Arch, J.; Adada, H.; van der Merwe, T. Why do African Americans get more colon cancer than Native Africans? J. Nutr. 2007, 137, 175S-182S.

(C) 2013 by the authors; licensee MDPI, Basel, Switzerland. This article is an open access article distributed under the terms and conditions of the Creative Commons Attribution license (http://creativecommons.org/licenses/by/3.0/). 